\title{
6. Exhibition destination attractiveness: dimensions and perceptual differences between exhibitors and visitors of China's exhibitions
}

\author{
Xin Jin and Karin Weber
}

\section{INTRODUCTION}

The exhibition industry has experienced substantial growth rates over the past few decades on a global scale. The continued growth can be credited to ever increasing trade and commerce across national boundaries, increased corporate travel budgets and the value marketers put on faceto-face contact with customers and leads (UFI 2012). The development of the exhibition industry in a region is also closely related to the state of its economic attributes, such as market leadership, industry sector characteristics and economic and spatial concentration (industry agglomeration). Furthermore, factors such as global economic environment, competition of the exhibition industry at the regional level and internal management challenges impact exhibition development (UFI 2012).

\section{CHINA'S EXHIBITION INDUSTRY}

Owing to the continent's thriving economy, Asia has become one of foci of global exhibition industry development (see, also, Golfetto and Rinallo, this volume). This has created a supportive environment for the growth of China's exhibition business. The country has been a leading player in the Asia-Pacific exhibition market, with its exhibition sector being regarded as a valuable platform to promote internal and external trade and commerce, as well as functioning as a revenue generator for host cities (Guo 2012). Its exhibitions have played a significant role in the breakthrough of Chinese brands and Chinese-made products into international markets. In 
2010, China had a total of 4.7 million square meters of indoor exhibition space, accounting for 15 percent of the world's total. This put the country in second place, following the U.S. and preceding Germany, in terms of domestic venue capacity (UFI 2011). In 2011, there were 153 convention and exhibition centers in 36 cities, with 28 of them having more than 80,000 square meters of indoor exhibition space (CCES 2012).

The 2008 global financial crisis and its repercussions have significantly affected the exhibition industry at a global level. Despite decreases in net exhibition space rented in Europe and North America, net exhibition space rented in China reached a new peak with 13 million square meters in 2010, a 6 percent increase over the previous year (UFI 2011). This demonstrates that China remains a strong growth market for exhibitions, consistent with practitioners' positive outlook towards China's exhibition industry. They attribute the expansion of the industry to a number of factors (UFI 2007), namely (i) the need to enlarge facilities to keep growing exhibitions from moving to other locations; (ii) the growing awareness by local authorities of the benefits of the industry, in terms of direct, indirect and induced economic impacts; and (iii) the coexistence of various economic models and financial expectations.

China hosted approximately 7,000 exhibitions of a diverse nature and scale in 2011, with machinery, building materials, food, textile, fashion and leather being the most actively and frequently exhibited industrial sectors (CCES 2012). Despite the rapid growth in exhibition activity, performance indicators indicate relatively low results for China. For instance, the average rental utilization rate (equivalent to the share of exhibition space rented out over the entire year) has been lingering around 15 to 20 percent over the past decade (Kay 2005; Guo 2012). Compared with international utilization rates of approximately 40 percent, space in purposebuilt centers in China has been under-utilized. This has especially been the case compared to facilities located in globally successful exhibition destinations. For example, the Hong Kong Convention and Exhibition Centre (HKCEC) had a high utilization rate of more than 70 percent (Cheung 2011). Occupancy rates of convention and exhibition space in Las Vegas varied from 40 to 72 percent in the period from 1997 to 2008, and this even triggered concerns regarding potential over-capacity (Yang and $\mathrm{Gu}$ 2012). The exhibition industry is becoming more and more mature and competitive, and, as a result, an exhibition center's performance is increasingly connected to a destination's competitive advantages, mainly market conditions, facilities, destination appeal, infrastructure, amenities, technology and management (Detlefsen and Vetter 2008). Thus, it is important to evaluate destination and venue attractiveness that can lead to potential demand. 
Based on city size, prestige, economic strength, tradition and history in hosting exhibitions, and the number of exhibitions held on an annual basis, Shanghai, Beijing and Guangzhou are typically classified as firsttier exhibition cities, whereas provincial capital cities or economically developed cities striving to build the exhibition industry are classified as second-tier cities (e.g. Chan 2007; Guo 2007). While first-tier cities have largely dominated the exhibition market over the past two decades, and consequently enjoy high occupancy rates of their exhibition venues, many state-of-the-art exhibition facilities constructed in second-tier cities across the country are under-utilized (see, for some exceptions, Bathelt and Zeng, this issue). As abundant exhibition space surpasses demand in most cities, it is critical to understand destination attributes that attract exhibitions to a city and fill exhibition space. Thus, it is of value to study factors that affect both exhibitors' and visitors' decisions to travel to a particular destination to attend a specific exhibition. A poor understanding of their behavior may ultimately result in a waste of scarce resources.

This chapter reports key findings of a series of studies that focused on an assessment of exhibition destination attractiveness attributes (see, also, Zhu and Zeng, this volume) from the perspective of two primary stakeholders in the exhibition context, namely exhibitors and visitors. The objectives of this chapter are (i) to identify dimensions of exhibition destination attractiveness from the perspectives of both stakeholders, (ii) to investigate the importance of these dimensions and (iii) to compare perceptions of the stakeholders, with respect to first-tier and second-tier cities. We introduce the methodology for our various studies next, before reporting key findings and detailing study implications.

\section{METHODOLOGY}

To investigate this, a series of empirical studies focusing on exhibition destination attractiveness have been conducted since 2008. In particular, an extensive survey program was administered to investigate factors influencing exhibition destination attractiveness and the subsequent impact of these factors. Surveys were conducted in five cities across China at ten exhibitions of varied nature. Both exhibitors and visitors were interviewed.

Table 6.1 reports the host city, venue, exhibition scale (in terms of the number of exhibitors), exhibitor and visitor samples obtained and organizer characteristics of these exhibitions. When choosing survey exhibitions and locations, consideration was given to sample international and national exhibitions of diverse ownership, staged in venues in both 


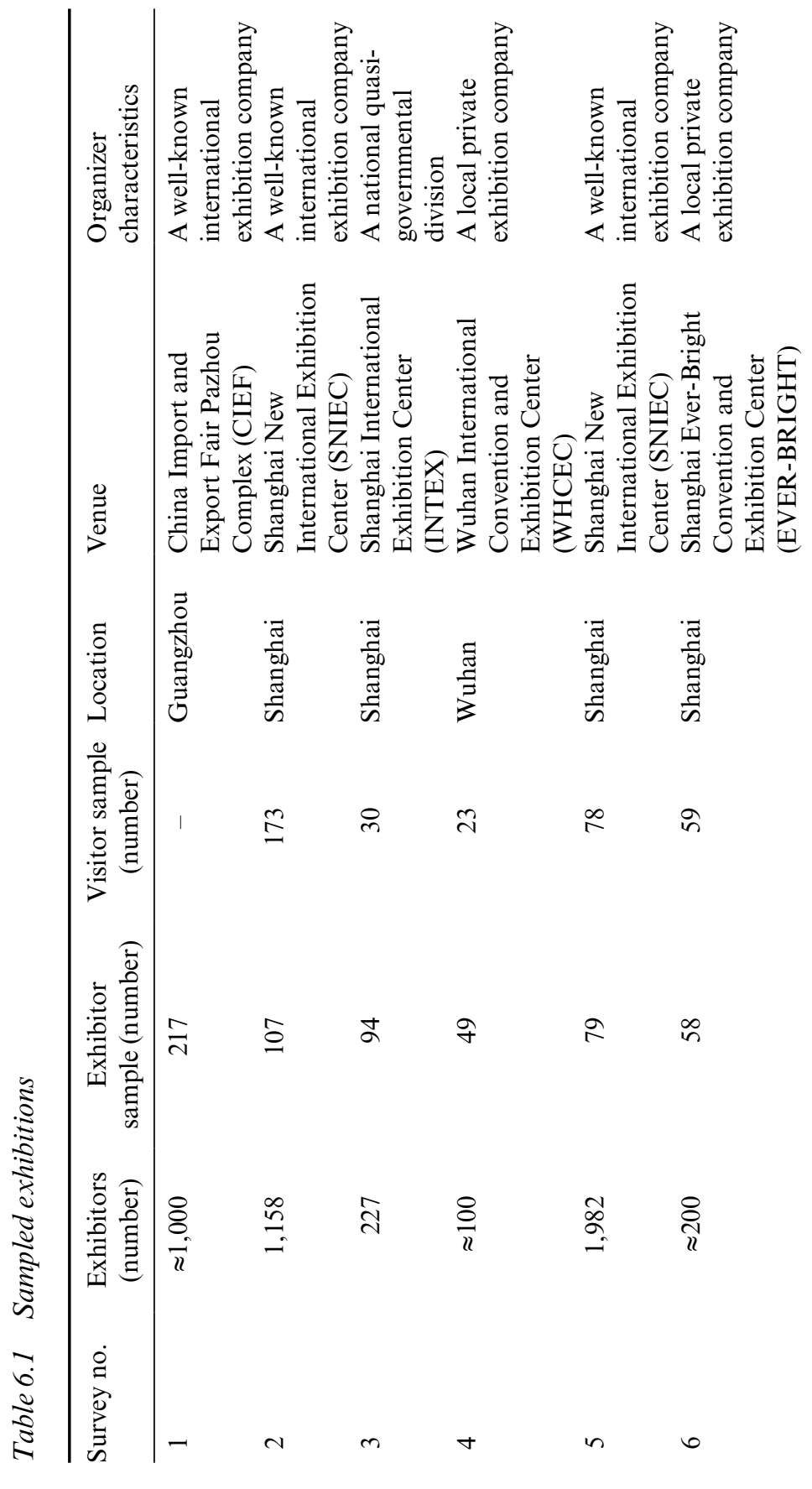




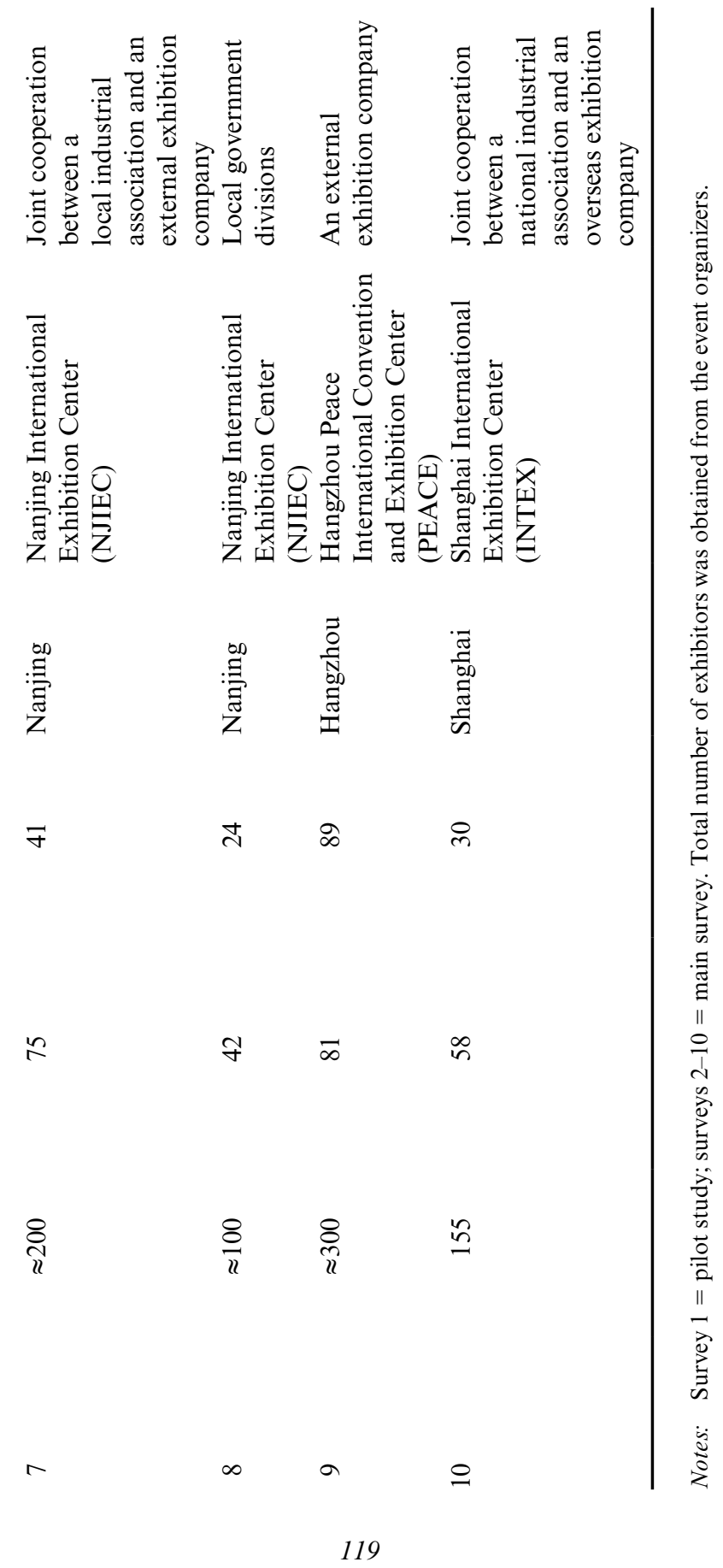


first-tier and second-tier cities and covering varied industry sectors. The pilot test obtained 217 valid exhibitor responses from an exhibition hosted in Guangzhou. The main survey covered nine further exhibitions in four cities in China's Yangtze River and Pearl River Deltas and collected 643 responses from exhibitors and 547 responses from visitors. Prior to analysis, data was screened for entry errors and missing values that may impair the data analyses. This resulted in 215 valid responses for the pilot test, 616 valid responses from exhibitors and 535 valid responses from visitors for the main survey. Although this excluded exhibitions in other second-tier or third-tier destinations, given the leading position of the two regions in China's exhibition industry, the sampled exhibitions and destinations can be considered crucial to the overall population.

The statistical analysis was conducted using SPSS 12.0/18.0 and AMOS Graphics 17.0/19.0. The exhibitor and visitor data were analyzed separately, applying the same methodology. Exploratory factor analysis (EFA) was first utilized to explore the dimensionality of the destination attractiveness factors. Varimax rotation was employed for each EFA analysis. The dimensionality was then tested and verified by conducting confirmatory factor analysis (CFA). Two steps were taken in CFA to validate the EFA factor solutions. Initially, first-order CFA was conducted to verify the dimensionality. Then second-order CFA was conducted to confirm that exhibition destination attractiveness consists of the proposed sub-dimensions. The models were solved using maximum-likelihood. The standard factor loadings, t-values, squared multiple correlations (SMC), composite reliability (CR) and average variance extracted (AVE) were used to indicate the reliability and validity of the CFA models. In the following analysis, only CFA results are reported. Differences in perceptions of destination attractiveness variables were assessed between exhibitors/ visitors in exhibitions hosted in one first-tier city (Shanghai) versus exhibitors/visitors in exhibitions hosted in three second-tier cities (Hangzhou, Wuhan and Nanjing). Thus, independent sample t-tests were conducted at the factor level, based on the CFA results.

\section{FINDINGS}

This section reports the findings of both exhibitor and visitor analysis of destination attractiveness. It is organized according to the steps of the data analysis (i.e. first-order CFA results, second-order CFA results and t-test results). Differences between the exhibitor and visitor data are discussed in each sub-section. 


\section{(i) Factors of Exhibition Destination Attractiveness}

Several measures for exhibition destination attractiveness were identified in the context of China's exhibition industry, drawing on first-order CFA. From the perspective of exhibitors, and with the details reported in Table 6.2, destination attractiveness attributes fall into six distinct dimensions:

1. destination leisure environment

2. cluster effect 1 (host city leadership in the industry)

3. venue facilities

4. accessibility

5. cluster effect 2 (host city/region as a source of exhibitors)

6. destination economic environment.

Of particular interest are the two dimensions that can be related to clustering effects: (i) host city leadership in the industry and (ii) host city/region as a source of exhibitors. These effects refer to the perceived impact of the clustering of industries and/or manufacturing firms in the host region on the respective industries' exhibition activities from the perspective of exhibitors (and visitors). The factor host city leadership in the industry was characterized by high factor loadings (which represent correlations between the factors and items) for items such as the host city being an important distribution hub of a specific industry sector, having support from related industries and possessing a strong professional industry association. The factor host city/region as a source of exhibitors had high loadings for items related to the proximity of the host city to the manufacturing base of the exhibited sector, as represented by suppliers and distributors located in the respective city or nearby regions.

In contrast, from the perspective of exhibition visitors, and with details reported in Table 6.3, destination attractiveness attributes fall into five distinct dimensions:

1. cluster effect 2 (host city/region as a source of exhibitors)

2. destination leisure environment

3. destination economic environment

4. venue facilities

5. accessibility.

The main difference between exhibitors' and visitors' perceptions is that the clustering effect 1 (leadership of the host city in the industrial sector for exhibition) is the most important factor for exhibitors in evaluating 
Table 6.2 Factors/items of exhibition destination attractiveness for exhibitors - First order confirmatory factor analysis

\begin{tabular}{|c|c|c|c|c|}
\hline Factor/item & $\begin{array}{l}\text { Standard } \\
\text { loading }\end{array}$ & t-value & SMC & $\mathrm{CR}$ \\
\hline Destination leisure environment & & & & 0.80 \\
\hline I feel safe in this city. & 0.740 & 10.375 & 0.558 & \\
\hline The weather in this city is pleasant. & 0.661 & $\mathrm{n} / \mathrm{a}$ & 0.437 & \\
\hline $\begin{array}{l}\text { The local people of this host city are } \\
\text { friendly. }\end{array}$ & 0.705 & 9.531 & 0.467 & \\
\hline This city has many tourist attractions. & 0.610 & 8.697 & 0.351 & \\
\hline This city is clean. & 0.651 & 9.234 & 0.417 & \\
\hline I have no language barriers in this city. & 0.505 & 7.591 & 0.255 & \\
\hline $\begin{array}{l}\text { Cluster effect } 1 \text { (Leadership of the host city } \\
\text { in the industry) }\end{array}$ & & & & 0.64 \\
\hline $\begin{array}{l}\text { There is a strong professional } \\
\text { association of our industrial sector } \\
\text { in this city. }\end{array}$ & 0.614 & 9.695 & 0.405 & \\
\hline $\begin{array}{l}\text { This city is an important distribution hub } \\
\text { of our industrial sector in China. }\end{array}$ & 0.596 & $\mathrm{n} / \mathrm{a}$ & 0.355 & \\
\hline $\begin{array}{l}\text { This city has support from industries } \\
\text { related to this exhibition. }\end{array}$ & 0.773 & 9.477 & 0.598 & \\
\hline $\begin{array}{l}\text { This city is a leading city of an industrial } \\
\text { belt where most products/equipment in } \\
\text { this exhibition is manufactured. }\end{array}$ & 0.633 & 8.472 & 0.401 & \\
\hline Venue facilities & & & & 0.80 \\
\hline $\begin{array}{l}\text { The exhibition center layout is easy for } \\
\text { people to find their way. }\end{array}$ & 0.748 & 11.294 & 0.559 & \\
\hline $\begin{array}{l}\text { Transportation to this exhibition center is } \\
\text { convenient. }\end{array}$ & 0.645 & 9.998 & 0.416 & \\
\hline $\begin{array}{l}\text { The location of this exhibition center is } \\
\text { excellent. }\end{array}$ & 0.535 & 8.316 & 0.286 & \\
\hline $\begin{array}{l}\text { This exhibition center has sufficient space } \\
\text { to accommodate this exhibition. }\end{array}$ & 0.721 & $\mathrm{n} / \mathrm{a}$ & 0.520 & \\
\hline $\begin{array}{l}\text { The facilities of the exhibition center are } \\
\text { excellent. }\end{array}$ & 0.699 & 10.441 & 0.483 & \\
\hline Accessibility & & & & 0.75 \\
\hline $\begin{array}{l}\text { It is easy to get information about this host } \\
\text { city. }\end{array}$ & 0.765 & 9.237 & 0.587 & \\
\hline It is easy to get to the city. & 0.705 & 9.095 & 0.491 & \\
\hline $\begin{array}{l}\text { The geographical location of this host city } \\
\text { is convenient. }\end{array}$ & 0.662 & $\mathrm{n} / \mathrm{a}$ & 0.442 & \\
\hline
\end{tabular}


Table 6.2 (continued)

\begin{tabular}{|c|c|c|c|c|}
\hline Factor/item & $\begin{array}{c}\text { Standard } \\
\text { loading }\end{array}$ & t-value & $\mathrm{SMC}$ & $\mathrm{CR}$ \\
\hline $\begin{array}{l}\text { Cluster effect } 2 \text { (Host city/region as sources } \\
\text { of exhibitors) }\end{array}$ & & & & 0.74 \\
\hline $\begin{array}{l}\text { China's manufacturing firms in our } \\
\text { industry are especially located in this city } \\
\text { or nearby regions. }\end{array}$ & 0.595 & 8.23 & 0.361 & \\
\hline $\begin{array}{l}\text { Most suppliers in this exhibition are } \\
\text { located in this city or nearby regions. }\end{array}$ & 0.714 & $\mathrm{n} / \mathrm{a}$ & 0.517 & \\
\hline $\begin{array}{l}\text { Most distributors of the products/ } \\
\text { equipment exhibited come from this city } \\
\text { or nearby regions. }\end{array}$ & 0.781 & 10.617 & 0.593 & \\
\hline Destination economic environment & & & & 0.75 \\
\hline $\begin{array}{l}\text { The overall economic condition of this city } \\
\text { is among the top five in China. }\end{array}$ & 0.657 & 8.627 & 0.441 & \\
\hline $\begin{array}{l}\text { This city has a large number of } \\
\text { international firms. }\end{array}$ & 0.881 & $\mathrm{n} / \mathrm{a}$ & 0.747 & \\
\hline
\end{tabular}

Notes: $\quad \chi^{2}=435.279, \mathrm{df}=211, \mathrm{p}<0.001 ; \chi^{2} / \mathrm{df}=2.063$; Goodness-of-Fit Index $=0.886$; $\mathrm{CFI}=0.914 ; \mathrm{RMSEA}=0.060, \mathrm{n}=293 . \mathrm{CR}=$ Composite Reliability; $\mathrm{SMC}=$ Squared Multiple Correlations; CFI = Comparative Fit Index; RMSEA = Root Mean Square Error of Approximation.

exhibition destination attractiveness, whereas it is not identified as an important factor by visitors. Only clustering effect 2 (host city/region as sources of exhibitors) is recognized as an important factor by visitors.

\section{(ii) Importance of Destination Attractiveness Attributes}

In the next step of our analysis, the importance of destination attractiveness factors was measured, drawing on second-order CFA of both exhibitor and visitor data (see Table 6.4). From the perspective of exhibitors, clustering effect 1 (host city leadership in the industry) had the greatest impact on exhibition destination attractiveness, followed by venue facilities and clustering effect 2 (host city/region being a source for exhibitors). Results show that exhibitors were aware of and preferred host city destinations in which clustering effects exist that developed over time. This supports arguments that the maturity of an industry in a destination is important to the development of exhibitions for that specific industry sector (Chan 2005; Butler et al. 2007), and that exhibitions mirror local/ 
Table 6.3 Factors/items of exhibition destination attractiveness for visitors - First-order confirmatory factor analysis

\begin{tabular}{|c|c|c|c|c|}
\hline Factor/item & $\begin{array}{l}\text { Standard } \\
\text { loading }\end{array}$ & SMC & t-value & $\mathrm{CR}$ \\
\hline $\begin{array}{l}\text { Cluster effect } 2 \text { (Host city/region as } \\
\text { sources of exhibitors) }\end{array}$ & & & & 0.71 \\
\hline $\begin{array}{l}\text { China's manufacturing firms in our } \\
\text { industry are especially located in this } \\
\text { city or nearby regions. }\end{array}$ & 0.650 & 0.422 & $\mathrm{n} / \mathrm{a}$ & \\
\hline $\begin{array}{l}\text { Most distributors of the products/ } \\
\text { equipment exhibited come from this city } \\
\text { or nearby regions. }\end{array}$ & 0.702 & 0.492 & 11.449 & \\
\hline $\begin{array}{l}\text { Most suppliers in this exhibition are } \\
\text { located in this city or nearby regions. }\end{array}$ & 0.663 & 0.439 & 11.175 & \\
\hline Destination leisure environment & & & & 0.82 \\
\hline $\begin{array}{l}\text { The local people of this host city are } \\
\text { friendly. }\end{array}$ & 0.714 & 0.509 & $\mathrm{n} / \mathrm{a}$ & \\
\hline The environment of this city is clean. & 0.709 & 0.503 & 14.628 & \\
\hline This city has many tourist attractions. & 0.700 & 0.490 & 14.460 & \\
\hline The weather in this city is pleasant. & 0.795 & 0.632 & 16.060 & \\
\hline Destination economic environment & & & & 0.83 \\
\hline $\begin{array}{l}\text { Compared with other cities in China, the } \\
\text { cost of exhibiting in this city (excluding } \\
\text { booth rental fees) is low. }\end{array}$ & 0.584 & 0.341 & $\mathrm{n} / \mathrm{a}$ & \\
\hline $\begin{array}{l}\text { The business environment of this city is } \\
\text { excellent. }\end{array}$ & 0.773 & 0.598 & 12.967 & \\
\hline $\begin{array}{l}\text { This city has support from industries } \\
\text { related to this exhibition. }\end{array}$ & 0.784 & 0.614 & 13.062 & \\
\hline $\begin{array}{l}\text { This city has a large number of } \\
\text { international firms. }\end{array}$ & 0.795 & 0.632 & 13.154 & \\
\hline Venuе facilities & & & & 0.77 \\
\hline $\begin{array}{l}\text { This exhibition center has sufficient space } \\
\text { to accommodate this exhibition. }\end{array}$ & 0.582 & 0.339 & $\mathrm{n} / \mathrm{a}$ & \\
\hline $\begin{array}{l}\text { The exhibition center layout is easy for } \\
\text { people to find their way. }\end{array}$ & 0.810 & 0.656 & 12.627 & \\
\hline $\begin{array}{l}\text { The facilities of the exhibition center are } \\
\text { excellent. }\end{array}$ & 0.777 & 0.604 & 12.464 & \\
\hline Accessibility & & & & 0.71 \\
\hline It is easy to get to the city. & 0.637 & 0.406 & $\mathrm{n} / \mathrm{a}$ & \\
\hline $\begin{array}{l}\text { It is easy to get information about this } \\
\text { host city. }\end{array}$ & 0.556 & 0.309 & 10.380 & \\
\hline
\end{tabular}


Table 6.3 (continued)

\begin{tabular}{lcccc}
\hline Factor/item & $\begin{array}{c}\text { Standard } \\
\text { loading }\end{array}$ & SMC & t-value & CR \\
\hline $\begin{array}{l}\text { The geographical location of this host city } \\
\text { is convenient. }\end{array}$ & 0.597 & 0.356 & 11.001 & \\
$\begin{array}{l}\text { Transportation to this exhibition center is } \\
\text { convenient. }\end{array}$ & 0.674 & 0.454 & 11.982 & \\
\hline
\end{tabular}

Notes: $\quad \chi^{2}=436.438, \mathrm{df}=123, \mathrm{p}<0.001 ; \chi^{2} / \mathrm{df}=3.548$; Goodness-of-Fit Index $=0.921$; $\mathrm{CFI}=0.914$; RMSEA $=0.069($ Lo90 $=0.062, \mathrm{Hi90}=0.076), \mathrm{n}=535 . \mathrm{CR}=$ Composite Reliability; SMC = Squared Multiple Correlations; Hi and Lo indicates the range of RMSEA values.

regional economic and industry development (Kirchgeorg 2005; see, also, $\mathrm{Li}$, this volume; Rinallo and Golfetto, this volume). From the standpoint of exhibitors, accessibility and a destination's economic and leisure environments also had a significant impact on exhibition destination attractiveness (as SMC values of the three constructs are all above 0.4 ), albeit to a lesser extent compared to the clustering factors. The economic environment was measured by strong economic conditions and the presence of a large number of international firms. This is in line with previous studies that stress the importance of the economic standing of an exhibition destination (e.g. Fuchslocher 2005; Rubalcaba-Bermejo and Cuadrado-Roura 1995).

From the perspective of visitors, although all factors had a significant impact on destination attractiveness, accessibility had the greatest impact, followed by venue facilities and leisure environment, whereas economic environment and clustering effects were less important compared to the other factors. The main difference between exhibitors' and visitors' perceptions is that clustering effect 1 (leadership of the host city in the industrial sector for exhibition) was the most important factor for exhibitors in evaluating exhibition destination attractiveness, but was much less important for visitors. By contrast, accessibility was less important for exhibitors but represented the most important factor for visitors.

All of this indicates that successful large-scale trade shows may have potential to expand to second-tier cities. This finding is well aligned with an earlier study (Jin et al. 2010) that reported findings of a survey conducted in Guangzhou in 2008. Duplicate shows are frequently held in second-tier cities with the aim to attract similar groups of exhibitors and visitors as the original events. Our earlier study explored respondents' preferences of China's second-tier cities as potential host destinations for 
Table 6.4 Factors/items of exhibition destination attractiveness for (i) exhibitors and (ii) visitors - Second-order confirmatory factor analysis

(i) Exhibitors

\begin{tabular}{|c|c|c|c|c|c|}
\hline Factor/item & $\begin{array}{l}\text { Standard } \\
\text { loading }\end{array}$ & t-value & SMC & AVE & $\mathrm{CR}$ \\
\hline Destination attractiveness & & & & 0.59 & 0.90 \\
\hline $\begin{array}{l}\text { Cluster effect } 1 \text { (Host city leadership } \\
\text { in the industry) }\end{array}$ & 0.969 & 10.647 & 0.939 & 0.41 & 0.73 \\
\hline Venue facilities & 0.804 & 10.467 & 0.647 & 0.44 & 0.80 \\
\hline $\begin{array}{l}\text { Cluster } 2 \text { (Host city/region as a } \\
\text { source of exhibitors) }\end{array}$ & 0.737 & $\mathrm{n} / \mathrm{a}$ & 0.543 & 0.48 & 0.73 \\
\hline Destination leisure environment & 0.712 & 9.941 & 0.506 & 0.43 & 0.82 \\
\hline Destination economic environment & 0.702 & 10.401 & 0.492 & 0.58 & 0.82 \\
\hline Accessibility & 0.665 & 9.155 & 0.442 & 0.51 & 0.75 \\
\hline
\end{tabular}

Notes: $\quad \chi^{2}=712.831, \mathrm{df}=220, \mathrm{p}<0.001 ; \chi^{2} / \mathrm{df}=3.240$; Goodness-of-Fit Index $=0.905$; $\mathrm{CFI}=0.909 ; \mathrm{RMSEA}=0.060, \mathrm{n}=616 . \mathrm{SMC}=$ Squared Multiple Correlations; $\mathrm{CFI}=$ Comparative Fit Index; AVE = Average Variances Extracted; RMSEA = Root Mean Square Error of Approximation.

(ii) Visitors

\begin{tabular}{lccccc}
\hline Factor/item & $\begin{array}{c}\text { Standard } \\
\text { loading }\end{array}$ & t-value & SMC & AVE & CR \\
\hline $\begin{array}{l}\text { Destination attractiveness } \\
\text { Accessibility }\end{array}$ & 0.893 & 13.207 & 0.797 & 0.45 & 0.71 \\
$\begin{array}{l}\text { Venue facilities } \\
\begin{array}{l}\text { Destination leisure } \\
\quad \text { environment }\end{array}\end{array}$ & 0.778 & 11.241 & 0.605 & 0.53 & 0.82 \\
$\begin{array}{l}\text { Destination economic } \\
\quad \text { environment }\end{array}$ & 0.715 & 9.996 & 0.511 & 0.53 & 0.77 \\
\begin{tabular}{l} 
Cluster effect \\
\hline
\end{tabular} & 0.672 & 10.541 & 0.452 & 0.38 & 0.71 \\
\hline
\end{tabular}

Notes: $\quad \chi^{2}=391.075, \mathrm{df}=112, \mathrm{p}<0.001 ; \chi^{2} / \mathrm{df}=3.492 ;$ Goodness-of-Fit Index $=$ 0.923 ; CFI $=0.914 ;$ RMSEA $=0.068($ Lo90 $=0.061$, Hi90 $=0.076), \mathrm{n}=535 . \mathrm{SMC}=$ Squared Multiple Correlations; CFI = Comparative Fit Index; AVE = Average Variances Extracted; RMSEA = Root Mean Square Error of Approximation; Hi and Lo indicates the range of RMSEA values. 
a large-scale international beauty and cosmetic trade show that was held at the time in Guangzhou (Jin et al. 2010). Findings indicated that visitors rated a destination's leisure environment attributes very highly, whereas exhibitors rated a destination's business environment higher, when considering what may influence their exhibition attendance decision-making. This difference indicates that, while exhibitors may go anywhere where there is potential for successful business, visitors prefer exhibition destinations with good accessibility to minimize travel time and with an attractive leisure environment that offers some degree of enjoyment in addition to taking care of business.

\section{(iii) Perceptual Differences of Exhibition Destination Attractiveness between Exhibitors and Visitors, with Respect to First-Tier and Second-Tier Cities}

Potential differences in the attractiveness of first-tier and second-tier cities as exhibition destinations were separately explored for exhibitors and visitors, utilizing independent sample t-tests. Table 6.5 reports differences in perceptions of both exhibitors and visitors, comparing those who attended exhibitions in a first-tier city with those attending exhibitions in secondtier cities.

Our study results provide interesting additional insights. From the exhibitors' perspective, the first-tier city Shanghai attracted higher ratings for the factors economic environment, clustering effect 1 and clustering effect 2, but had slightly lower ratings in accessibility and leisure environment than the three second-tier cities Nanjing, Hangzhou and Wuhan. Independent sample t-tests showed that there was a significant difference in terms of cluster 1 (leadership of host city in the industry), economic standing of the destination and leisure environment, indicating that exhibitors regard a first-tier city's economic standing and leadership quite highly, but valued the leisure environment higher in second-tier cities. There was no significant difference between first-tier and second-tier cities in terms of venue facilities, destination as a source of exhibitors, and accessibility. This suggests that second-tier cities were perceived as having venue facilities and accessibility at least on par with the first-tier city Shanghai.

Comparing perceptions of visitors who attended exhibitions in the first-tier city with those who attended exhibitions in second-tier cities, the former gave higher ratings in only two dimensions: economic environment and venue facilities. However, only the difference in ratings for economic environment was significant and there was no significant difference in the ratings of venue facilities between visitors in the first-tier city and the second-tier cities, resonating with exhibitors' perceptions 
Table 6.5 Factors of exhibition destination attractiveness for ( $i$ ) exhibitors and (ii) visitors - First-tier versus second-tier cities

(i) Exhibitors

\begin{tabular}{|c|c|c|c|c|c|c|c|}
\hline \multirow[t]{2}{*}{ Factor } & \multicolumn{2}{|c|}{$\begin{array}{l}\text { First tier } \\
(\mathrm{n}=379)\end{array}$} & \multicolumn{2}{|c|}{$\begin{array}{l}\text { Second tier } \\
(\mathrm{n}=236)\end{array}$} & \multirow[t]{2}{*}{$\begin{array}{c}\text { Mean } \\
\text { difference }\end{array}$} & \multirow[t]{2}{*}{ t-value } & \multirow[t]{2}{*}{ Significance } \\
\hline & Mean & Rank & Mean & Rank & & & \\
\hline $\begin{array}{l}\text { Economic } \\
\text { environment }\end{array}$ & 5.97 & 1 & 4.28 & 6 & 1.70 & 16.193 & $0.000^{*}$ \\
\hline Accessibility & 5.52 & 2 & 5.59 & 1 & -0.06 & -0.649 & 0.512 \\
\hline $\begin{array}{l}\text { Leisure } \\
\text { environment }\end{array}$ & 5.16 & 3 & 5.40 & 2 & -0.24 & -2.699 & $0.007^{*}$ \\
\hline Cluster effect 1 & 5.14 & 4 & 4.68 & 4 & 0.46 & 4.976 & $0.000 *$ \\
\hline Venue facilities & 5.00 & 5 & 5.03 & 3 & -0.030 & -0.304 & 0.761 \\
\hline Cluster effect 2 & 4.80 & 6 & 4.67 & 5 & 0.13 & 1.227 & 0.220 \\
\hline
\end{tabular}

Note: $*$ significant at $\chi \leq 0.05$

(ii) Visitors

\begin{tabular}{lcccccccc}
\hline Factor & \multicolumn{2}{c}{$\begin{array}{c}\text { First tier } \\
(\mathrm{n}=324)\end{array}$} & & \multicolumn{2}{c}{$\begin{array}{c}\text { Second tier } \\
(\mathrm{n}=166)\end{array}$} & $\begin{array}{c}\text { Mean } \\
\text { difference }\end{array}$ & t-value & Significance \\
\cline { 2 - 3 } & Mean & Rank & & Mean & Rank & & & \\
\hline $\begin{array}{l}\text { Economic } \\
\quad \text { environment }\end{array}$ & 5.415 & 1 & & 5.054 & 4 & 0.362 & -7.151 & $0.000^{*}$ \\
$\begin{array}{l}\text { Venue facilities } \\
\text { Accessibility }\end{array}$ & 5.317 & 2 & & 5.292 & 3 & 0.025 & 0.741 & 0.459 \\
$\begin{array}{l}\text { Leisure } \\
\quad \text { Environment }\end{array}$ & 5.234 & 3 & & 5.744 & 2 & -0.511 & -2.772 & $0.006^{*}$ \\
$\begin{array}{l}\text { Cluster } \\
\text { effect 2 }\end{array}$ & 4.831 & 5 & 5.964 & 1 & -0.752 & -7.922 & $0.000^{*}$ \\
\hline
\end{tabular}

Note: $*=$ significant at $\chi \leq 0.05$

that differences in exhibition venues were insignificant. Interestingly, visitors rated Shanghai significantly lower in terms of accessibility, leisure environment and clustering effect than visitors of the second-tier cities. Overall, visitors' perceptions resonated with those of exhibitors that second-tier cities have better accessibility and leisure environments. This may be due to the vast expansion of Shanghai as an urban center, with inner city transportation having consequently become more difficult and 
time-consuming. Conversely, the three second-tier cities possess excellent transportation networks that offer easy access to exhibition venues. Nanjing and Hangzhou are also well known as pleasant and atmospheric tourist destinations.

\section{DISCUSSION AND CONCLUSION}

This chapter summarizes findings of two studies (Jin et al. 2012; Jin and Weber 2013) on factors influencing exhibition destination attractiveness, from the perspective of (i) exhibitors and (ii) visitors who attend exhibitions in China. Findings indicate that exhibitors and visitors have different views on clustering effects (i.e. the localization of exhibitions in close proximity to corresponding agglomerations of respective industries and/ or exhibitors) as one of the most important factors that comprise exhibition destination attractiveness. Findings also indicate that exhibitors and visitors rate first-tier and second-tier cities similarly in terms of attractiveness, suggesting that there may be good prospects for second-tier cities to develop as exhibition destinations.

The findings confirm prior propositions by several researchers (e.g. Chan 2005; Rubalcaba-Bermejo and Cuadrado-Roura 1995) about the link between industry agglomerations and exhibition destination development. This link is also observed in exhibitors' responses. A twodimensional scale was developed to measure clustering effects in the exhibition industry, related to (i) host city leadership in the industry and (ii) host city as a source of exhibitors. The impact of these two clustering effects on exhibition destination attractiveness appears to be different. First, the two dimensions bear different weights of importance on perceived destination attractiveness. Second, the two dimensions indicate a different impact of agglomeration patterns between first-tier and secondtier cities on exhibition development. A first-tier exhibition city has a strong leadership status and is typically a major city, defined in terms of population and economic output. Its pattern of industrial clustering encompasses a larger variety of industry sectors, whereas in second-tier or third-tier cities a more specialized pattern of industrial concentration develops. This resonates with Rubalcaba-Bermejo and Cuadrado-Roura's (1995) argument that larger cities have a higher level of industry diversification and a larger number of exhibitions. Clustering effect 1 explains the leadership of a few gateway cities in exhibition development. Thus, the three first-tier cities in China's exhibition industry - Shanghai, Beijing and Guangzhou as the leading cities of the three largest industrial belts (i.e. the Yangtze River Delta, Beijing-Tianjin and Pearl River Delta Industrial 
Belts) - could strengthen their leadership further in the future. Gateway cities have more of a competitive edge as they may gain support from several clusters in their surrounding region. Clustering effect 2 provides support for the development of exhibitions in such second-tier or thirdtier cities where manufacturing facilities/factories are concentrated. It also explains why some specialized exhibitions hosted in smaller cities are well recognized by exhibitors. However, second-tier or third-tier cities with more specialized industrial agglomerations may have to bear in mind that it may be difficult for them to develop exhibitions for which they do not possess a clustering effect advantage. It is also noted in our analysis that exhibitors and visitors have different perceptions of clustering effects and assign varying weights to these effects in relation to overall exhibition destination attractiveness. Generally speaking, the clustering effects on exhibition destination attractiveness are more important to exhibitors than they are to visitors.

China's exhibition industry development shows some similarities with the patterns observed in Germany and Italy, where exhibitions gained strength due to clustering effects and economic development of the host regions, resulting from both the legacy of past industrial developments and current rapid advances (Brenner and Gildner 2006). Given the perceived importance of clustering effects from the exhibitors' perspective, it is likely difficult to start an exhibition in a city in China without respective clustering advantages. This is different compared to exhibitions that developed, for example, in Las Vegas, where exhibition development is based on available space, professional operation and touristic value (e.g. Yang and $\mathrm{Gu} 2012$ ) rather than clustering effects. For successful exhibition destinations in China, cities with a favorable leisure environment in terms of tourist facilities, safety and cleanliness may also be competitive in developing exhibitions. Accessibility as measured by location, ease of access to the city and ease of acquiring information about the city was perceived as important in our study, lending support to similar findings in previous studies on convention site selection and exhibition center success factors (e.g. Hiller 1995; Rubalcaba-Bermejo and Cuadrado-Roura 1995; Crouch and Louviere 2004). Since second-tier cities were rated favorably in terms of accessibility, leisure environment and venue facilities, these cities could be successful when developing larger exhibitions to attract both exhibitors and visitors.

Finally, it must be pointed out that exhibition destination attractiveness factors constitute a necessary, but not sufficient condition for destinations to successfully attract and retain exhibitions. Exhibition-related factors were found to be more important to establish and retain an exhibition in a locality, with organizer performance and key show features 
being key factors in exhibitors' and visitors' attendance decision-making, compared to a destination's macro and business environment (Jin et al. 2010). Specifically, the relationship between organizers and exhibitors, as manifested in trust, commitment, organizer service quality and relationship satisfaction, is a determining factor for exhibition brand preference from the exhibitors' perspective (Jin and Weber 2013). Thus, the success of an exhibition and the establishment of exhibition brands depend on exhibitions meeting both exhibitors' needs and objectives, in addition to the organizers' ability to build trust and commitment with exhibitors. Destination attractiveness factors play an important role, as services provided by organizers are inseparable from the quality of venue facilities and services.

\section{REFERENCES}

Brenner, T. and Gildner, A. (2006) 'The long-term implications of local industrial clusters', European Planning Studies, 14 (9): 1315-1328.

Butler, C., Bassiouni, Y., El-Adly, M. and Widjaja, A. (2007) 'Revamping the value chain in exhibition facilities: The case of the Dubai exhibition industry', Facilities, 25 (11/12): 419-436.

CCES - China Convention and Exhibition Society (2012) Statistics and Analysis Report of China's Exhibition Industry 2011, Beijing: CCES. Online. Available HTTP: <http://www.cces2006.org/report/> (20 March 2013).

Chan, C. (2005) Exhibition Theory and Practice, Shenzhen: Haitian Publications.

Chan, C. (2007) On Spatial Distribution of China's Exhibitions, Beijing. Online. Available HTTP: <http://www.cnki.net> (4 October 2009).

Cheung, W. (2011) Hong Kong Trade Exhibition - An Industry Review (Phase 2), Hong Kong: The Chinese University of Hong Kong, BMT Asia Pacific. Online. Available HTTP: <http://www.legco.gov.hk/yr11-12/english/panels/ci/papers/ ci1115cb1-661-1-e.pdf> (12 April 2014).

Crouch, G. I. and Louviere, J. J. (2004) 'The determinants of convention site selection: A logistic choice model from experimental data', Journal of Travel Research, 43 (2): 118-130.

Detlefsen, H. and Vetter, N. (2008) Convention Centers: Is the Industry Overbuilt? 2008 Update, HVS. Online. Available HTTP: <http://www.hvs.com/article/3180/ convention-centers-is-the-industry-overbuilt-2008/> (12 November 2013).

Fuchslocher, H. (2005) 'Analysis of exhibitors - An instrument of fair controlling', in M. Kirchgeorg, W. Giese and W. Dornscheidt (eds) Trade Show Management: Planning, Implementing and Controlling of Trade Shows, Conventions and Events, Wiesbaden: Gabler, 287-303.

Guo, J. (2007) The Report on Development of China's Convention and Exhibition Economy 2006-2007, Beijing: Social Sciences Academic Press.

Guo, J. (2012) Annual Report on China's Convention and Exhibition Economy 2012, Beijing: Social Sciences Academic Press.

Hiller, H. (1995) 'Conventions as mega-events: A new model for host-host city relationships', Tourism Management, 16 (5): 375-379. 
Jin, X., Bauer, T. and Weber, K. (2010) 'China's second-tier cities as exhibition destinations', International Journal of Contemporary Hospitality Management, 22 (4): 552-571.

Jin, X. and Weber, K. (2013) 'Developing and testing a model of exhibition brand preference: The exhibitors' perspective', Tourism Management, 38: 94-104.

Jin, X., Weber, K. and Bauer, T. (2012) 'Impact of clusters on exhibition destination attractiveness: Evidence from Mainland China', Tourism Management, 33 (6): 1429-1439.

Kay, A. (2005) 'China's convention and exhibition center boom', Journal of Convention and Event Tourism, 7 (1): 5-22.

Kirchgeorg, M. (2005) 'Characteristics and forms of trade shows', in M. Kirchgeorg, W. Giese and W. Dornscheidt (eds) Trade Show Management: Planning, Implementing and Controlling of Trade Shows, Conventions and Events, Wiesbaden: Gabler, 33-56.

Rubalcaba-Bermejo, L. and Cuadrado-Roura, J. R. (1995) 'Urban hierarchies and territorial competition in Europe: Exploring the role of fairs and exhibitions', Urban Studies, 32 (2): 379-400.

UFI - The Global Association of the Exhibition Industry (2007) The World Map of Exhibition Venues and Future Trends, Paris: UFI. Online. Available HTTP: <http://www.ufinet.org/media/publicationspress/2007_ufi_world_map_ of_exhibition_venues.pdf> (10 February 2008).

UFI (2011) Global Exhibition Industry Statistics, 2011, Paris: UFI. Online. Available HTTP: <http://www.ufi.org/Medias/pdf/thetradefairsector/2011_ exhibiton_industry_statistics.pdf $>$ (9 November 2012).

UFI (2012) The Global Exhibition Barometer - Survey of the Exhibition Industry, Paris: UFI. Online. Available HTTP: <http://www.ufi.org/Medias/pdf/thetradefairsector/surveys/ufi_global_exhibition_barometer_july_2012.pdf $>$ (20 March 2013).

Yang, L.-T. and Gu, Z. (2012) 'Capacity optimization analysis for the MICE industry in Las Vegas', International Journal of Contemporary Hospitality Management, 24 (2): 335-349. 